\title{
Combining anti-CTLA4 with RG7787, an immunotoxin targeting mesothelin, promotes tumor eradication
}

\author{
Jasmin Leshem ${ }^{1 *}$, Xiu-fen Liu', Tapan Bera ${ }^{1}$, Masaki Terabe ${ }^{2}$, Jay A Berzofsky ${ }^{3}$, Birgit Bossenmaier ${ }^{4}$, \\ Gerhard Niederfellner ${ }^{4}$, Ira Pastan ${ }^{1}$
}

From 30th Annual Meeting and Associated Programs of the Society for Immunotherapy of Cancer (SITC 2015) National Harbor, MD, USA. 4-8 November 2015

\section{Introduction}

Antibodies to cytotoxic T-lymphocyte-associated protein 4 (CTLA4) potentiate an immune response against cancer. Response rates in melanoma patients are range from 10 to 19\%[1]. To increase the efficacy and variety of cancer types treated by anti CTLA4, a combination therapy should be pursued. RG7787 is a recombinant immunotoxin composed of an anti-mesothelin Fab fused to a fragment of Pseudomonas exotoxin A (PE). RG7787 is currently tested in phase 1 trials for mesothelin expressing malignancies. We previously observed that an anti-mesothelin immunotoxin produced major tumor regressions in humans with advanced mesothelioma when combined with Cytoxan and Pentostatin apparently due to $\mathrm{T}$ cell activation[2] and we are exploring other ways to activate the immune system when cells are killed by immunotoxin. We hypothesize that combining RG7787 with anti CTLA4 will promote activation of the immune system and cancer elimination.

\section{Methods}

We transfected the 66C14 mouse breast cancer cell line with human mesothelin and grew the cancer cells in immune-competent BALB/c mice that express a human mesothelin transgene so that they will not reject the tumors. The transfected cells are killed by RG7787 in cell culture $\left(I C_{50} 12 \mathrm{ng} / \mathrm{ml}\right)$. Anti-tumor activity was evaluated by intra tumoral-injection of RG7787 combined with intra-peritoneal injection of anti CTLA4.

'Laboratory of Molecular Biology, National Cancer Institute, Bethesda, MD,

USA

Full list of author information is available at the end of the article

\section{Results}

We found that combining RG7787 with anti CTLA4 produced a $76 \%$ complete remission (CR) rate, while $\mathrm{CR}$ was reached in only $15 \%$ of the mice under anti CTLA4 monotherapy. The survival benefit was statistically significantly $(\mathrm{P}=0.0012)$. No mice reached $\mathrm{CR}$ after treatment with RG7787 alone or in the PBS treated controls. Furthermore, re-challenging of the mice that reached CR with the parental cell line $(66 \mathrm{C} 14$ without human mesothelin) resulted in complete rejection of the tumor in all the mice. We also found treatment with antibodies to $\mathrm{CD} 8$ decreased the $\mathrm{CR}$ rate to $12 \%$, indicating that $\mathrm{CD}^{+} \mathrm{T}$ cells are necessary for the response.

\section{Conclusions}

Combining RG7787 with anti CTLA4 produces a high rate of complete remissions in a breast cancer model.

\begin{abstract}
Authors' details
'Laboratory of Molecular Biology, National Cancer Institute, Bethesda, MD USA. ${ }^{2}$ National Cancer Institute, Bethesda, MD, USA. ${ }^{3} \mathrm{NCI} / \mathrm{CCR}$ Naccine Branch, Bethesda, MD, USA. ${ }^{4}$ Roche Pharmaceutical Research \&Early Development, Discovery Oncology, Innovation Center Penzberg, Roche Diagnostics $\mathrm{GmbH}$, Penzberg, Germany.
\end{abstract}

Published: 4 November 2015

\section{References}

1. Larkin J, Chiarion-Sileni V, Gonzalez R, Grob JJ, Cowey CL, Lao CD, et al: Combined Nivolumab and Ipilimumab or Monotherapy in Untreated Melanoma. N Engl J Med 2015, 373(1):23-34

2. Hassan R, Miller AC, Sharon E, Thomas A, Reynolds JC, Ling A, et al: Major cancer regressions in mesothelioma after treatment with an antimesothelin immunotoxin and immune suppression. Sci Transl Med 2013, 5(208):208ra147 
doi:10.1186/2051-1426-3-S2-P190

Cite this article as: Leshem et al:: Combining anti-CTLA4 with RG7787,

an immunotoxin targeting mesothelin, promotes tumor eradication.

Journal for ImmunoTherapy of Cancer 2015 3(Suppl 2):P190.

Submit your next manuscript to BioMed Central and take full advantage of:

- Convenient online submission

- Thorough peer review

- No space constraints or color figure charges

- Immediate publication on acceptance

- Inclusion in PubMed, CAS, Scopus and Google Scholar

- Research which is freely available for redistribution

Submit your manuscript at www.biomedcentral.com/submit 